University of Nebraska - Lincoln

DigitalCommons@University of Nebraska - Lincoln

Papers in the Earth and Atmospheric Sciences

Earth and Atmospheric Sciences, Department

6-1895

\title{
IS DAEMONELIX A BURROW?: A REPLY TO DR. THEODOR FUCHS
}

\author{
Erwin Hinckley Barbour \\ University of Nebraska-Lincoln
}

Follow this and additional works at: https://digitalcommons.unl.edu/geosciencefacpub

Part of the Earth Sciences Commons

Barbour, Erwin Hinckley, "IS DAEMONELIX A BURROW?: A REPLY TO DR. THEODOR FUCHS" (1895).

Papers in the Earth and Atmospheric Sciences. 333.

https://digitalcommons.unl.edu/geosciencefacpub/333

This Article is brought to you for free and open access by the Earth and Atmospheric Sciences, Department of at DigitalCommons@University of Nebraska - Lincoln. It has been accepted for inclusion in Papers in the Earth and Atmospheric Sciences by an authorized administrator of DigitalCommons@University of Nebraska - Lincoln. 


\section{PLATE XXIV.}

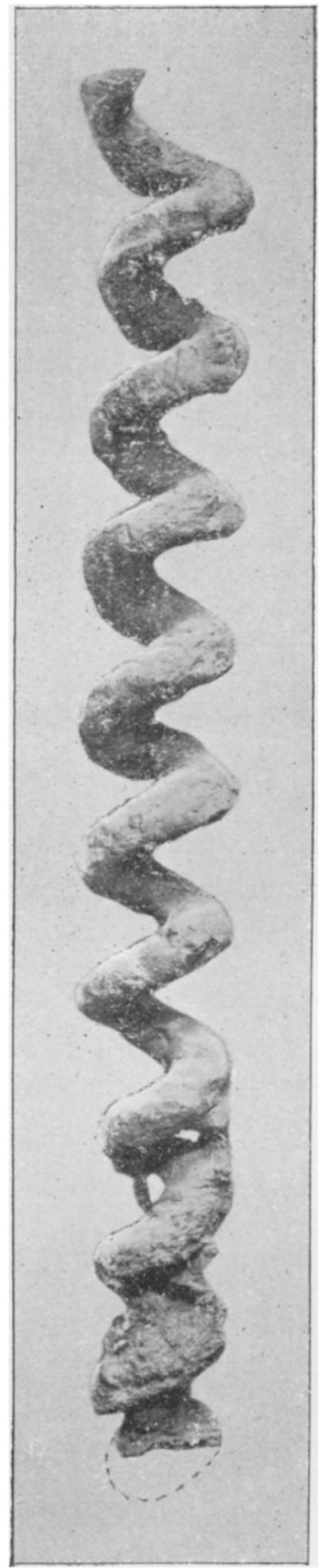

Fig. 1.

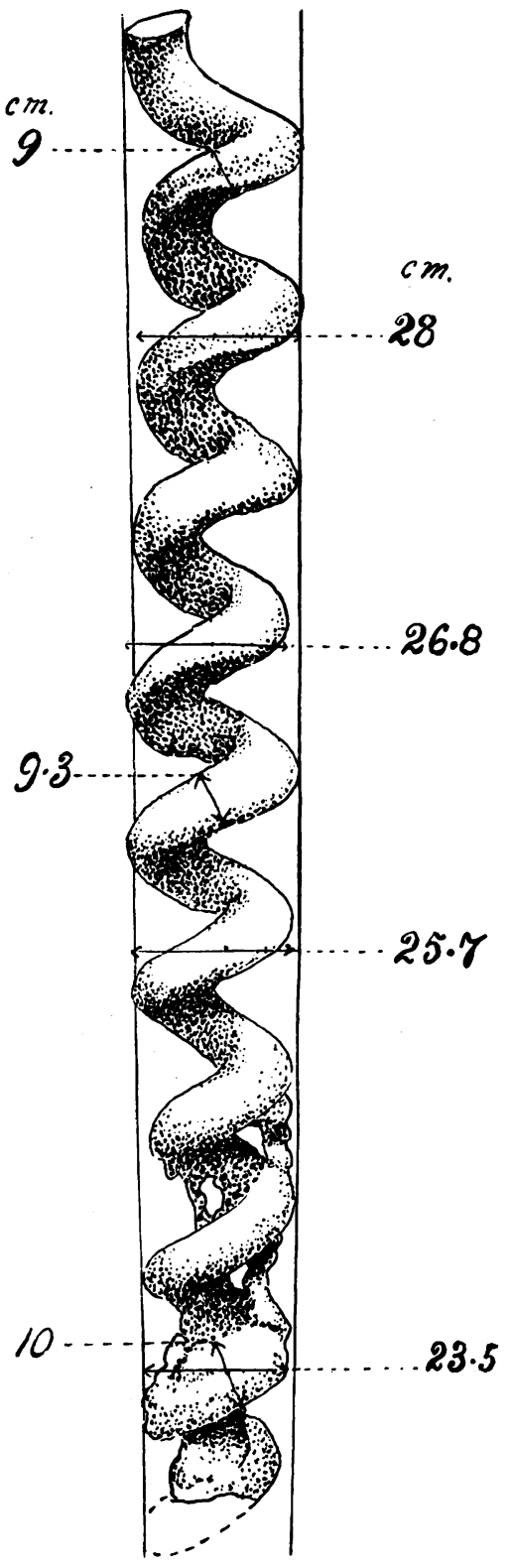

FIG. 2.

Frg. 1.-A typical Daemonelix without axis (The balance of this specimen is still in the rocks at Eagle Crag, Sioux Co., Nebr.). From a photograph of the specimen in the Morrill (Collection, State Museum, University of Nebraska. (See Fig. 2.)

Fig. 2.--Diagrammatic figure of Daemonelix, giving measurements (See Fig. 1.) Height 2.3 meters. 


\section{THE}

\section{AMERICAN NATURALIST}

VoL. XXIX.

June, 1895 .

342

IS DAEMONELIX A BURROW ?

A reply to Dr. Theodor Fuchs.

By Erwin Hinckley Barbour.

Dr. Theodor Fuchs, criticises at considerable length the nature of Daemonelix as described by the author, in the University Studies, of the University of Nebraska, Vol. I, No. 4, July, 1892, under the title, 'Notes on a New Order of Gigantic Fossils.'

When the criticism first appeared it seemed so fraught with errors that they were counted its own best rebuttal, and no attempt to frame a reply was thought of. However, the author has several times of late been reminded that these errors might pass muster and become fixed in the minds of those, at least, who place too implicit reliance in authority. Therefore in all justice to himself and to those who have been entirely misguided and misinformed the author thinks it better, perhaps, to correct certain errors and inaccuracies.

After carefully describing the burrows of the supposed Miocene gopher, citing as important proof the rodent found inside of one specimen of Daemonelix, and after quoting Gesner on the 'Habit of the Pouched Rat' Geomys pineti, of Georgia, he writes :

${ }^{1}$ In Annalen k. k. Naturhistorichen Hofmuseums, Wein, 1893, Pages 91 to 94. 35 
"I think we have before us all the essential elements of Daemonelix, and that accordingly we are justified in viewing these strange fossils as nothing else in reality than the underground homes of Miocene rodents, apparently of the family Geomyidæ. ${ }^{2}$ Thereby it is very easy to explain why these spirals are found invariably in upright positions; why they are never prostrate, bent or broken. Also why, in spite of their massive size, no organic substance is present. But further the nature of the deposit in which these strange bodies occur sheds unexpected light.

"According to the representations and drawings of the author, these Daemonelix are in the Miocene deposits of the Bad Lands, and are not confined to one stratum but they occur in the entire mass of these layers, and one very frequently sees sides of the hills more than one hundred feet high, from bottom to top, studded with the screws, but especially with the rootstalk which projects everywhere on the sides of the hills.

"Under such circumstances these Miocene deposits can not possibly be those of an inland sea, but we must regard them as essentially continental formations for the most part of subäerial origin; the same as our Loess, as the pampas formation, and many similar ones.

"The assertion of the author, that the rock in which Daemonelix occurs is a very homogeneous fine sandstone, agrees very well with the above conception."

${ }^{2}$ The same conception of Daemonelix could have been found in the American Naturalist for June, 1893 as proposed by Dr. E. D. Cope.

${ }^{3}$ Ich glaube, dass wir heir alle wesentlichen Elemente eines Daimonelix vor uns haben, und dass wir demnach berechtigt sind, in diesen sonderbaren Fossilien wirklich nichts Anderes als die unterirdischen Wohnungen miocäner Nagethiere, warscheinlich aus der Verwandtschaft von Geomys zu sehen.

Hiedurch erklärt sich ganz einfach, warum man diese Schraubenköper ausnahmslos in verticaler aufrechter Stellung findet, warum. sie niemals umgefallen, umgebogen oder zerbrochen erscheinen, ebenso auch warum trotz ihres massigen Baues keine organische Substanz in ihnen vorhanden ist.

Aber auch auf die Natur der Ablagerungen, in welchen diese sonderbaren Körper auftreten, wird hierdurch ein unerwartetes Licht geworfen.

Nach der Darstellung und den Zeichnungen des Verfassers sind diese Daimonelix in den Miocänbildungen der Bad Lands durchaus nicht auf eine bestimmte Schicht beschränkt, sondern sie kommen durch die ganze Masse dieser Ablager- 
The foregoing argument when summed up reads about as follows: Daemonelix is a burrow (false premise); burrows can not exist in water; therefore the Miocene of the Bad Lands are wind deposits (false conclusion). No valid argument can be based on the assumption of the point to be established and proved.

A premise, as the name signifies, is something antecedently established or proved, therefore the argument is based on the false premise that Daemonelix is a burrow, which is not an established fact, but is the fact which he is to establish. If the premise is false, so is the conclusion, and we find it remarkably exemplified in this case. The startling and extraordinary conclusion is, that the well-known region of the Miocene Bad Lands is a wind deposit, and not a water deposit, as it is known the world over to be. It is argument in a circle. It is not logical nor are the deductions geological. It is a pure assumption that Daemonelix is a burrow, but so easily is the mind led from pure assumptions to the conviction of their truth, that we find the author under consideration unhesitatingly pronouncing the well-known Miocene Bad Lands an aërial deposit, and denying that it is aqueous. That such a mistake could ever have been made is to be explained away on the ground of undue haste. No naturalist could deliberately pronounce our Miocene Bad Lands anything but water deposits.

Those famous Miocene beds are not wind deposits. They are not Loess. They are exactly what he says they are not, -water deposits. The Bad Lands are among the best known

ung vor, und man sieht sehr häufig Wände von mehreren 100 Fuss Höhe von unten bis oben von den Schrauben, noch mehr aber von den "Wurzelstöcken" erfüllt, welche überall an den Wänden hervorragen.

Unter solchen Verhältnissen können aber diese Miocänablagerungen umöglich Ablagerungen eines Binnensees sein, sondern wir müssen sie der Hauptsache nach für continentale Bildungen ansehen welche, wahrscheinlich grossentheils subeerischen Ursprungs in ähnliche Weise gebildet werden wie unser Löss, wie die Pampasformation und viele andere ähnliche Bildungen.

Die Angabe des Verfassers, dass das Gestein, in welchem die Daimonelix vorkommen, ein äusserst homogener, feiner Sandstein ist, stimmt mit dieser Auffassung sehr gut überein. 
and most celebrated formations in the world, and are recognized as stratified aqueous deposits by every geologist.

Unless the foregoing syllogism is right and all geologists wrong, then Dr. Fuchs' gopher is left to burrow and build its nest of dry hay in one or two hundred fathoms of Miocene water.

The White River tertiary is an extensive deposit covering parts of Nebraska, Dakota and Wyoming. The depth of the deposit was originally, and still is, nearly 1,000 feet in thickness, and the time required for its deposition is estimated at 25,000 to 30,000 years. It is so plainly stratified that inexperienced students, members of my geological excursions to these regions, could make out the strata and follow them with certainty at sight. They could recognize the Titanotherium beds, lower, middle, and upper, and follow them about as they would follow the lower, middle and upper boards of an ordinary fence. So with the Oreodon beds, Metamynodon sandrock, Protoceras and others. All is stratification there, and that too so strikingly and conspicuously that no one can overlook or mistake it. The Loess, or Bluff Deposits, at the best are but obscurely stratified. They occur in southern Nebraska, Iowa, northern Kansas, and Missouri, 200 or 300 miles south of the region under discussion.

No wind could ever have formed the perfectly stratified and minutely laminated deposits of the Bad Land region. It can be formed by the assorting power of water and by that only. It is, of course, true that modern winds are functional in producing certain local surface configurations, but primarily the deposit was aqueous throughout.

He says-"It is not clear what the author writes concerning the structure of the body of Daemonelix. According to him the same seems to be filled with fine tubes, which wind about each other and give the body a spongy structure, a circumstance which the author advances, and seizes upon as important proof of the organic structure of the bodies.

"It is difficult to discuss the subject without having seen the specimen. Typical Loess is also filled with fine tubes which 
intertwining give it a tufaceous or sponge-like structure, yet it is in itself no organism."

The author is entirely cognisant of the fact that Loess is penetrated by tubes--but they are vertical rather than intertwining and ramifying,-whereby are produced lines of weakness in vertical planes. The result being manifest in the sides of cañons and bluffs which are as upright as walls. This it is that gives our bluff deposits their character. Of course, ordinary meteoric water, charged more or less with carbon dioxide, percolates readily through the porous Loess, where it finds superabundance of lime salts to be dissolved out. It finds easy passage through these tubes, and as evaporation goes on and the carbon dioxide is liberated, lime carbonate is deposited as a white lining to these tubes.

In the color, and in that alone, is there any similarity between the vertical tubes in Daemonelix and those of the Loess, although we are led to the inference that they are the same.

In chemical composition the two are totally unlike. The tubes of the Loess are entirely inorganic; those of the Daemonelix are entirely organic, as every section shows. There remains then not so much as a semblence of an analogy between the tubes of the Loess and those of the Daemonelix.

In reply to the description of the characteristic and very intricately tangled tubules on the surface of Daemonelix (Figured in Pl. III of the paper criticized) he asks, "Could not this tube structure originate from the dry grass of which the gopher built his nest?" It seems to me there are two very patent reasons why this can not be. In the first place the so-called hay is not confined to the region of the supposed nest, but covers every portion of the entire fossil. The burrow then in which the gopher presumably dwelt was literally tamped with fine hay from bottom to top. Where then did the gopher and his prolific family dwell ?

In the second place, if it were hay, the microscope would easily recognize it. But to the contrary the microscope shows it is not hay, because there are no fibro-vascular bundles, which grass would of necessity show; nor is there a trace of the siliceous epidermal layer which would certainly be 
preserved in grasses. Nor is the arrangement of cells that of hay, but it is instead that of soft parenchymatous tissue of seaweeds or rootlets.

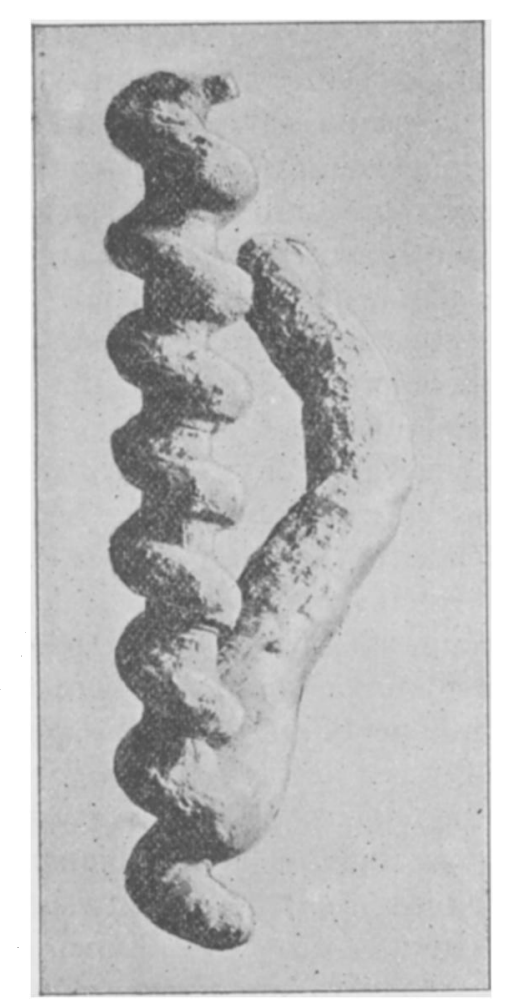

As for the size and general appearance, I may explain here that these tubules are not unlike a tangle of rootlets in a flower pot.

In a semi-arid region, such as this, plants are variously modified to withstand drought. Some send down roots to unusual depths, and it often happens that wells are entirely filled with great masses of fibrous rootlets especially of the cottonwood.

If we can conceive of the burrow being thus occupied it would agree much better with its general structure than hay. It would represent it still more closely if we conceive of a burrow, row, possibly abandoned, and subsequently lined by

Fig. 3.-A typical Daemonelix with axis. a felt of some imaginary From a photograph of a specimen in the MorrillCollection, State Museum, University fucoid. However, in view of Nebraska. For measurements see Fig. 5 of all the facts, the foregoing seems untenable, and the author, although conceiving of the idea long ago, cannot believe this to be merely a vegetable lining to a burrow. Microscopic sections suggest the sea-weed, the structure being very simple. It is cellular but never vascular. It seems to me then that any attempt to show that these tubules are possibly hay, must miscarry.

"If the spiral is a filled up burrow so is the axis also, and one must admit that apparently the animal, after it had dug 
the spiral burrow, in order to shorten the exit, dug yet another straight one."

"Possibly the animal used both burrows alternately, the comfortable winding one when it returned home with booty laden pouches; the shorter straight passage when it emerged light and unloaded."

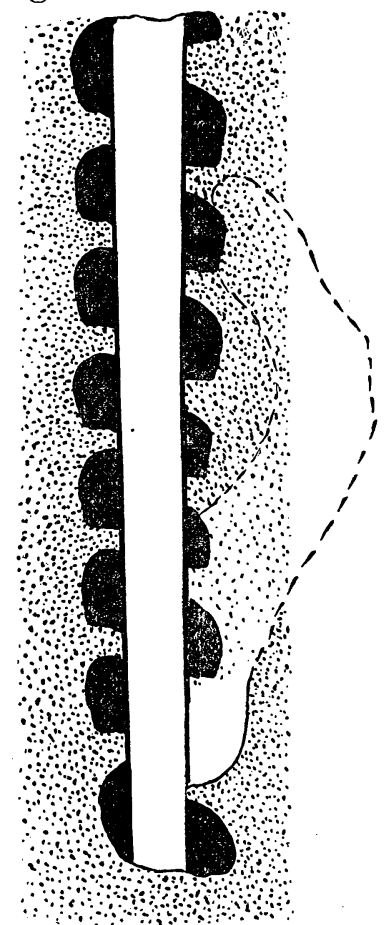

Fig. 4.-A diagrammatic figure showing the difficult, if not the mechanical impossibility of building a burrow in sand. The "Spiral Burrow" is colored black; the "Straight Burrow" is left white. The sand is represented by stippling.
"The author's observation agrees very well with this that each Daemonelix which has no central axis, but consists simply of a free spiral, has, as a rule, no transverse piece. One must certainly consider these as incomplete structures in which the side canal, with its nest and the central canal, are not yet finished."

It seems to me that the visionary argument in the foregoing crumbles as would such a burrow before it is half done. See Fig. 4. Conceive of a hollow rotunda in sand encircled by a spiral stairs and you have thought out a physical and mechanical impossibility. Grant that the sand was coherent enough to hold together till the burrow was done Can it be presumed for a moment that it could withstand the wear and tear of gophers climbing straight up this hollow passage? Yet the fossils show not a notched, scratched or rounded angle. If the Miocene gopher had burrowed in half lithified sandrock as coherent as that in which these fossils now occur, it could not resist the destruction which must result from gophers scurrying up and down its walls. But no specimen furnishes the slightest evidence of such wear. 
But there are other facts militating against this burrow theory, among which the following may be mentioned. The tangled tubules which so plainly characterize the entire surface of Daemonelix often appear diffused in great irregular masses, and in broad sheets, in certain places throughout the sand rock in Daemonelix beds.

In the case of those which occur in thin sheets in cracks and fissures it is impossible that any animal ever burrowed there. Some of this plant structure then is unquestionably disconnected entirely from any burrow. What is true then of part of this organic structure may possibly be true of the whole.

It is very common indeed to notice offshoots from these corkscrews either running as supports from one coil up to the next (See Fig. 1) or running out irregularly into the surrounding matrix. These vary from the size of one millimeter to one or more centimeters and have been traced to a length of half a meter to a full meter or more.

Now it is perfectly apparent that no gopher could possibly have constructed these narrow tubes. Granting that he constructed the spiral tube how are we to account for these numerous offshoots which could not have been constructed by a gopher.

If this is in truth the work of a gopher then it must stand as a lasting monument to the genius of that creature which laid the lines of his complex abode with such invariable precision and constancy. If it were that of any of the lower forms the surprise would be less.

The difficulty alone of digging a spiral with a constant and invariable pitch seems entirely beyond the instincts of higher animals such as these quick and reasoning creatures. But besides the constancy and accuracy of pitch of the helix comes another element of great complexity, the helix tapers from top to bottom with such nicety that this animated instrument of precision would have to be sensitive to differences, not exceeding one millimeter for every $90^{\circ}$, in its course around the axis of the spiral. Is such precision to be expected of animals endowed with reason? 
Without attempting to describe or discuss this point further the author has submitted certain figures which he believes will carry out the idea embodied in the foregoing much more tersely and emphatically than he could by verbal descriptions (See Figs. 2 and 5).

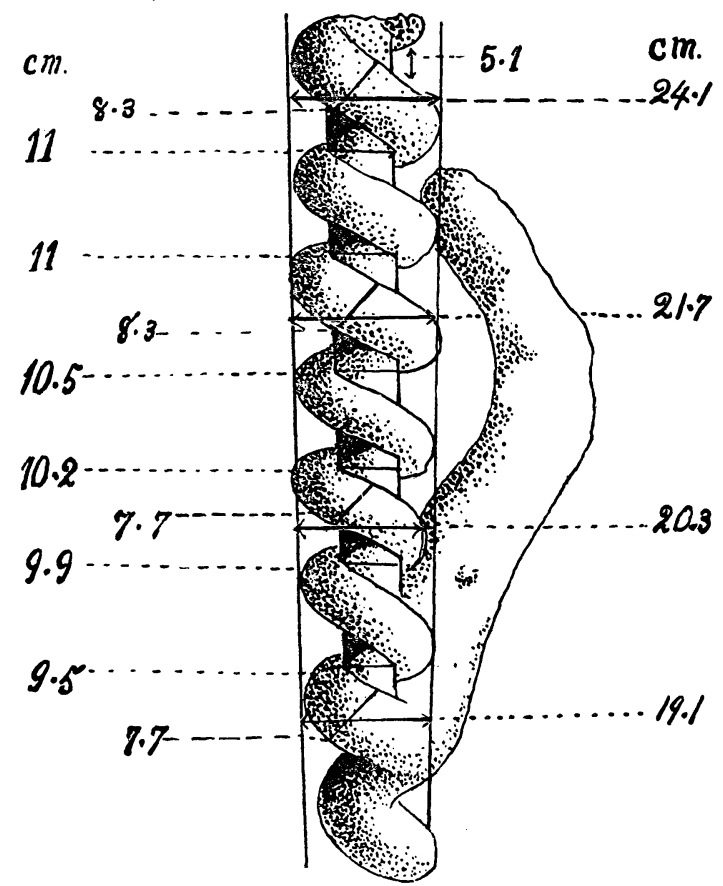

Fig. 5.-Diagrammatic figure of Daemonelix, giving measurements. (See Fig. 3.) Height 1.32 meters.

I believe that such precision could emanate only from the blind instinct of plants and lower animals unguided by reason.

In both papers (University Studies, Vol. I, No. 4, July, 1892, and Vol. II, No. 1, July, 1894) the author took pains to explain that he had found the skeleton of a rodent of exactly suitable size within the root-stalk at the base of a spiral. But in the next sentence he urged the recognition of the fact that at the same time one of his party, Mr. F. C. Kenyon, found the bones of a mammal as large as a deer, and altogether too large to have burrowed, yet it was likewise enclosed. The cork-screw 
spread out and conformed to the shape and size of the bones exactly as though it had been some growth which encased them. It was accordingly suggested that possibly the small rodent had been enclosed likewise.

Touching this point Dr. Fuchs writes "In my examination I am further strengthened by finding on closer reading that the author had, at one time, found the complete skeleton of a rodent within a so-called root-stalk at its anterior extremity. The author finds it entirely inexplicable how a rodent could occur within a root-stalk and undertakes to decide the case by declaring that the rodent was submerged and that the plant had settled down and completely grown around its skeleton. I believe, however, that the author had at hand the builder of Daemonelix."

Possibly this may be so. Certainly the author conceived of the idea months before it was published that there was such a fossil in existence. But in all justice, Dr. Fuchs should have mentioned the larger skeleton also. The smaller skeleton was enclosed within Daemonelix, so was the larger. Whatever is proof in case of one ought to hold with the other, or at the least ought to have some weight.

But this much is certain that no 100 centimeter Artiodactyle Ungulate can burrow in a 20 centimeter hole. That is to say the mere fact of finding bones thus encased is not in itself unconditional proof of a burrow.

Some may raise the objection that possibly the bones of this large Artiodactyle were deposited in the sand long before the gopher dug his burrow, and that it is merely an accident that the gopher's hole passed through, or in the vicinity of, the skeleton deposited there. Granting that this is so, then we have to face this condition; the gopher in digging his burrow, dug straight through this large skeleton, through vertebræ and limb-bones alike, and yet they are not disarticulated. The joints, to the metatarsals, are in place and the zygapophyses of the vertebræ are locked in their original position.

Now can any one conceive of the possibility of a gopher digging a 20 centimeter hole straight through such a skeleton yet leaving it entirely articulate. At the least it is improbable, 
and as I believe is impossible. However, if it is a possible case then it brings us to another condition; sedimentation must have gone on indefinitely long, the bones of the large animal were buried and covered by unknown feet of superimposed sediments, then the ancient lake was drained, erosion went on for an indefinite period cutting the surface into its present hills and valleys.

All this brings us then from Miocene to recent time, for it was in recent time, according to this, that the gopher must have dug his burrow through the bones of this old-time Artiodactyle. But it must be borne in mind in this connection that all these burrows are fossilized at the present time, and that the sand in which they occur is sandrock at the present time and must have been sandrock before the gopher dwelt there.

Can we believe that a gopher could excavate a burrow in rock too hard, often, even for our chisels and picks? Or has there been time for the fossilization of its burrow and bones on this supposition?

With the specimen in hand, grown over as it is with an organic network of tubules, the author can not believe that it can be accounted for in any other way than that already proposed; viz., that some organism quietly grew around these bones, conforming to their very shape and knitting them all together.

In still another case we found a small united radius and ulna in the matrix, on top of, and outside of, the root-stalk, just as if it had been deposited there as sedimentation went on One would naturally look for such bones within, not without the burrow; and on the bottom, not on the top.

The author would not be misunderstood in this reply. $\mathrm{He}$ does not deny the possibility of this being an old-time burrow, for such it may. yet prove to be despite his fondest hopes and his avowed convictions to the contrary, and despite the very plant structure itself. But he does attempt to deny that the Bad Lands are Loess of æolian origin; that the tubes in Daemonelix are Loess tubes; that the tubules and plant cells are those of hay; and that any gopher, Miocene or modern, could possibly construct in fine sand a straight burrow inside a spiral burrow which could stand.

University of Nebraska, Dec. 1st, 1894. 